\title{
Assessing diagnostic variations and correlates of fasting blood glucose
}

\author{
*Moke E.G., Edje K.E., Ojezele M.O., Emosivbe M
}

\begin{abstract}
Objective: To assess the diagnostic variables of blood glucose level among students of basic medical Sciences of Delta State University, Abraka Nigeria.

Methods: A descriptive cross sectional survey on a total of one hundred and ten (110) students of the Faculty of Basic Medical Science, Delta State University, Abraka was conducted. Descriptive statistics was used to analyze the differences in the data collected.

[

Results: The fasting blood glucose levels of $87.5 \%$ and $85 \%$ of the students had a normoglycemic level as indicated by the left and right thumb respectively. Also, a greater percentage $(69.1 \%)$ of the students were between the age range $21-25$. Furthermore, $72.7 \%, 76.4 \%$ and $64.5 \%$ of the students had normal weight, normal WHR and normal BP respectively.
\end{abstract}

Conclusion: There is no significant difference in the diagnostic assessment of blood glucose level using either right or left thumb.

Keywords: Fasting blood glucose, diabetes, diagnostic, Delta State, hypertension.

*Corresponding author.

Moke E.G.

ORCID-NO: http://orcid.org/0000-0002-4709-7474

E-mail: hiligoodies@gmail.com; Tel:+234-7061040692.

Department of Pharmacology and Therapeutics, Delta State University, Abraka, Delta State, Nigeria.

Research Journal of Health Sciences subscribed to terms and conditions of Open Access publication. Articles are distributed under the terms of Creative Commons Licence (CC BY-NC-ND 4.0). (http://creativecommons.org/licences/by-nc-nd/4.0).

http://dx.doi.org/10.4314/rejhs.v8i2.3 


\title{
Évaluation des variations diagnostiques et des corrélats de la glycémie à jeun
}

\author{
*Moke E.G., Edje K.E., Ojezele M.O., Emosivbe M
}

\section{Resume \\ Objectif:: Évaluer les variables diagnostiques de la glycémie chez les étudiants des sciences médicales de Delta State University, Abraka, Nigeria.}

Méthodes: Une enquête descriptive transversale sur un total de cent dix (110) étudiants de la Faculté des sciences médicales de base, Delta State University, Abraka a été menée. Des statistiques descriptives ont été utilisées pour analyser les différences dans les données collectées.

Résultats: Les taux de glycémie à jeun de $87,5 \%$ et $85 \%$ des étudiants avaient un niveau normo glycémique comme indiqué respectivement par le pouce gauche et le pouce droit. De plus, un pourcentage plus élevé $(69,1 \%)$ des élèves étaient âgés de 21 à 25 ans. De plus, $72,7 \%, 76,4 \%$ et $64,5 \%$ des élèves avaient respectivement un poids normal, un WHR normal et une TA normale.

Conclusion: Il n'y a pas de différence significative dans l'évaluation diagnostique de la glycémie à l'aide du pouce droit ou gauche.

Mots-clés: glycémie à jeun, diabète, diagnostic, état delta, hypertension.

*Corresponding author.

Moke E.G.

ORCID-NO: http://orcid.org/0000-0002-4709-7474

E-mail: hiligoodies@gmail.com; Tel:+234-7061040692.

Department of Pharmacology and Therapeutics, Delta State University, Abraka, Delta State, Nigeria. 


\section{INTRODUCTION}

The key substrate for the production of energy is the blood glucose. The level of blood glucose is usually maintained within a narrow physiological range except during the first few days (about 72 hours) of life where a marked physiological changes that represent a normal transition phase of glucose physiology (1). Most times, a rapid change in blood glucose level to either a lower or higher glucose levels (especially during meal) may be seen, but rapidly normalize within few minutes (2). Mechanism for this restoration is mediated partly by the glucogenic effect of the liver through glycogenolysis (breakdown of glycogen) and gluconeogenesis (production of glucose from a non-carbohydrate source such as lactate, alanine and glycerol) as well as several hormones have been implicated to regulate the level of glucose. These hormones are: insulin, glucagon, epinephrine, norepinerphrine, cortisol and growth hormone (GH) (1). While other hormones are implicated for the regulation of blood glucose levels during fasting state, insulin typically regulates blood glucose levels in postprandial state (1). Glucagon and epinephrine are the major key player hormones that prevent reduction in blood glucose level.

Assessment of blood glucose level can be done using several standard methods and the value of blood glucose level obtained can be described in four ways which are: hypoglycemia, normoglycemia (euglycemia), impaired fasting blood glucose level and hyperglycemia.

Hyperglycemia is characteristic of diabetes mellitus, although, not all patients with hyperglycemia can be said to be diabetics as it can also be seen among non - diabetics, resulting in significant morbidity and mortality (3). Stress (trauma) of any kind causes a bodily response characterized by enhanced metabolism and hyperglycemia. Stress-induced hyperglycemia occurs as a result of increased hepatic output of glucose rather than impaired tissue glucose extraction (3). Several factors may result in the rise in blood glucose level. Hence, the American Diabetes Association, stated that diabetes, is best regarded as a group of metabolic disorder with a common manifestation of persistent hyperglycemia (4).

There is a great increase in the several types of DM in Nigeria as well as globally (5). The International Diabetes Federation (6), report shows that 415 million adults between the ages of 20-79 worldwide are diabetics, however, about 642 million people will become diabetic by 2040 while, according to Tabak et al. (7), greater than 470 million people will be pre-diabetic (intermediate hyperglycemia) in 2030. From this estimate, 14.2 million adults aged 20 - 79 living in the African region are diabetic with an estimate of 1.6 million diabetic Nigerians. According to World Health Organization, International Diabetes Federation and the Diabetes Association of Nigeria, Report shows that Nigeria has the highest estimate of diabetics. About 321,000 cases of deaths due to diabetes were recorded by the International Diabetes Federation (6). However, a large percentage of people with diabetes in Nigeria remain undiagnosed and untreated.

Fasting blood glucose test being an important diagnostic tool for assessing the level of blood glucose; it can be influenced by several factors such as age, gender, physical activity, sleep, body mass index (BMI), waist circumference (WC), hip circumference (HC), waist-hip ratio (WHR), and systolic and diastolic blood pressure. However, there are sparse evidences showing the effect of these factors as well as variation from the body part (left thumb or right thumb) in which the blood was collected on FBG levels. This study evaluated the diagnostic variations of blood glucose level among students of basic medical sciences of Delta State University, Abraka Nigeria.

\section{MATERIALS AND METHODS}

A cross sectional survey was carried out in April, 2018 on a total of one hundred and ten (110) students between the ages of 15 - 30 years, spread across each department in the Faculty of Basic Medical Sciences, Delta State University, Abraka. Consent was sorted from the students before data collection. Of the total one hundred and ten (110) students included in the study population, twenty-two (22) students both male and female were selected from each department at random. Structured questionnaires were used to collect information on the possible risk factors that could affect fasting blood glucose. Variables assessed were socio-demographic data (department, level, gender, age, state of origin and ethnicity), blood glucose level, performance of physical activity, body mass index, central obesity index, and blood pressure (systolic and diastolic). Fasting blood glucose level measurement was carried out randomly on only forty students. Fasting blood glucose estimation for each student was done by pricking both right and left thumb of overnight fasted students (at least $8 \mathrm{~h}$ of not eating food) using Accu-check 
glucometer. Blood pressure measurement was assessed using a digital sphygmomanometer to measure both systolic and diastolic blood pressure for two consecutive periods after which the average of the two readings gotten was used. Students above age 30 and 100 level students were excluded from this study. Descriptive statistics was used to analyze the differences in the data collected based on their frequencies and simple percentages computed for the variables.

\section{RESULTS}

The socio-demographic pattern of respondents is presented in Table 1 . Most of the students were within the age of 21-25yrs (69.1\%). The majority of the students, $60(54.5 \%)$ were females. Forty students participated in the blood glucose test where both the right and left thumbs were sampled. The fasting blood glucose (FBG) of most students were normoglycemic (85\% with the right thumb and $87.5 \%$ with the left thumb) (Table 2). Frequent light physical exercise was common amongst the students (68\%). About $73 \%$ of the students were of normal weight, $9 \%$ overweight, and 7\% were obese. Majority $(76 \%)$ had normal values for waist/hip ratio. Blood pressure measurements were normal in $64.5 \%$ of the students, with $27.3 \%$ having pre-hypertension, $7.3 \%$ and $0.9 \%$ showed stages 1 and 2 of hypertension (Table 3-6).

\section{DISCUSSION}

The study of the diagnostic variations of blood glucose level amongst Basic Medical Sciences students of Delta State University, Abraka, Nigeria, showed that virtually all the students had normal FBG; impaired FBG or presumed diabetic FBG range seen in the rest few could be as a result of nervousness from fright for needle. On comparison of the tendency of variation in blood glucose level of blood sample collected from different part of the body using both thumbs (i.e., right and left thumb), showed a non-significant correlation between the values obtained using the left or the right. This was evident in this study as a greater percentage $(87.5 \%$ left thumb, $85 \%$ right thumb) of the students studied had their blood glucose levels within the normal range irrespective of the thumb. This proposes that either thumb can be used to sample for FBG test.

Age following several studies, has been implicated to decrease body metabolic functions. This was also confirmed from this study that age is a determinant on the regulatory pattern of blood glucose level, as a greater percentage $(69.1 \%)$ of the students studied within the age range $21-26$ had normal blood glucose level, who also make up the greater numbers of students studied. This significantly correlated with previous study performed by Oluwayemi and Oluwayemi (8), on 3,525 adolescents in three secondary schools out of which 628 adolescents who satisfied the inclusion criteria were studied and $70.7 \%$ of the studied adolescents had normal FBG levels.

This study showed a strong relationship between exercise and FBG as students who were involved in the physical exercises (light or vigorous) had normal FBG levels. Several studies have investigated the effect of varying intensity of exercise (physical activity) on glucose level $(9,10)$. Vinutha et al., (10) reported that the rate of glucose utilization was greater than the rate of glucose release following light exercise while at high intensity (vigorous) exercise, a significant increase in the rate of glucose release to the rate of glucose utilization was observed. This effect observed have been attributed to a disproportional rise in catecholamine levels which is known to mediate a rise in blood glucose levels (9). Other mechanisms implicated for this observed effect have been documented $(11,12)$.

Body mass index (BMI) is an important diagnostic tool for adiposity (13), and adiposity contributes to insulin resistance which relates to increase blood glucose levels. It was observed that $72.7 \%$ of the students had normal BMI which strongly relates with the normal FBG levels. Increase in blood glucose level have been associated with increase in lipid biosynthesis (lipogenesis) and hence, an increase in weight, hence, BMI has been implicated to show a significant correlation with FBG (14). Certain individuals may have a normal BMI, but an abnormal WHR which is an indicator of central or abdominal obesity. About seventy-six percent (76.4\%) of the students had normal WHR which may also account for the normal FBG levels seen with this study. This confirmed the report observed from other studies by Stepien et al., (15) and Veghari et al. (16).

In this study, there is a weak relationship between FBG and blood pressure due to the percentage of students with normal BP (64.5\%), pre-hypertension $(27.3 \%)$, and hypertension $(8.2 \%)$ as compared to the $87.5 \%$ with normal FBG, as these disease conditions are related. Researches have established that hypertension is more common in subjects with hyperglycemia (diabetes), and that hyperglycemia as well as higher fasting plasma glucose within the normal range is associated with a higher prevalence of 
hypertension $(17,18)$.

Therefore, the normal values of body mass index, waist/hip ratio, and blood pressure as reported in majority of the students could correlate the normal FBG profile observed.

\section{CONCLUSION}

The present study among Basic Medical Sciences students of Delta State University, Abraka, Nigeria, showed that diagnostic test for fasting blood glucose levels for disease conditions such as diabetes mellitus can be done by sampling blood from either the right thumb or the left thumb. Also, several factors such as age, physical activity, BMI and central obesity can affect fasting blood glucose level in apparently healthy individuals.

Conflicts of interest: The authors declare no conflicts of interest.

\section{REFERENCES}

1. Güemes M, Rahman SA, Hussain K. What is a normal blood glucose? Arch Dis Child. 2016; 101(6): 569-574.

2. Kaufman F. Role of the continuous glucose monitoring system in pediatric patients. Diabetes Technol Ther. 2000; 2(1): S49-52.

3. Goyal N, Kaur R, Sud A, Ghorpade N, Gupta M. Non diabetic and stress induced hyperglycemia $[\mathrm{SIH}]$ in orthopaedic practice: What do we know so far? J Clin Diagn Res. 2014; 8(10): 1 - 3

4. American Diabetes Association (ADA). Diagnosis and Classification of Diabetes Mellitus. Diabetes Care. 2010;33(S1): 62 - 69.

5. Oputa RN, Chinenye S. Diabetes in Nigeria-a translational medicine approach. African Journal of Diabetes Medicine. 2015; 23(1):7-10

6. International Diabetes Federation (IDF). IDF Diabetes atlas, 7th ed, 2015.

7. Tabák AG, Herder C, Rathmann W, Brunner EJ, Kivimäki M. Prediabetes: A high-risk state for developing diabetes. Lancet. 2012; 379(9833): 2279-2290.

8. Oluwayemi IO, Brink SJ, Oyenusi EE, Oduwole OA, Oluwayemi MA. Fasting Blood Glucose Profile among Secondary School Adolescents in Ado-Ekiti , Nigeria. 2015; 417859

9. Marliss EB, Vranic M. Intense exercise has unique effects on both insulin release and its roles in glucoregulation: implications for diabetes. Diabetes. 2002; 51(1): S271-283.
10. Vinutha S, Paul F, Raymond D, Adam R, Heather $R$, Nirubasini P, Matthew C, Elizabeth D, Timothy J. Effect of exercise intensity and blood glucose level on glucose requirements to maintain stable glycaemia during exercise in individuals with type 1 diabetes. Int $J$ Pediatr Endocrinol. 2015; 2015(Suppl 1): O39. doi: 10.1186/1687-9856-2015-S1-O39. Epub 2015 Apr 28. PMCID: PMC4428871.

11. Dean D, Daugaard JR, Young ME, Saha A, Vavvas D, Asp S, Kiens B, Kim KH, Witters L, Richter EA, Ruderman N. Exercise diminishes the activity of acetyl-CoA carboxylase in human muscle. Diabetes. 2000; 49(8): 1295-1300

12. Wilmore JH, Green JS, Stanforth PR, Gagnon J, Rankinen T, Leon AS, Rao DC, Skinner JS, Bouchard C. Relationship of changes in Maximal and Submaximal Aerobic Fitness to Change in NIDD. Relationship of changes in maximal and submaximal aerobic fitness to changes in cardiovascular disease and non-insulindependent diabetes mellitus risk factors with endurance training: the HERITAGE Family Study. Metabolism. 2001; 50(11): 1255-1263

13. Vittal BG, Praveen G, Deepak P. A Study of Body Mass Index in Healthy Individuals and Its Relationship with Fasting Blood Sugar. J Clin Diagnostic Res. 2010; 4(6):3421-3424.

14. Innocent O, ThankGod OO, Sandra EO, Josiah IE. Correlation between body mass index and blood glucose levels among some Nigerian undergraduates. HOAJ Biol. 2013; 2(1):4.

15. Steppan CM, Bailey ST, Bhat S, Brown EJ, Banerjee RR, Wright CM, Patel HR, Ahima RS, Lazar MA. The hormone resistin links obesity to diabetes. Nature. 2001; 409(6818): 307-12

16. Veghari $G$, Sedaghat $M$, Joshaghani $H$, Banihashem S, Moharloei P, Angizeh A, Tazik E, Moghaddami A, Hajian-Talaki K, ZahedPasha Y. The association of fasting blood glucose (FBG) and waist circumference in northern adults in Iran: a population based study. J. Diabetes Metab Disord. 2014; 13:2

17. $\mathrm{Fu} \mathrm{SN}$, Luk W, Wong $\mathrm{CK}$, Cheung KL. Progression from impaired fasting glucose to type 2 diabetes mellitus among Chinese subjects with and without hypertension in a primary care setting. J Diabetes. 2014; 6:438-46.

18. Yan Q, Sun D, Li X, Chen G, Zheng Q, Li L, Gu C, Feng B. Association of Blood Glucose Level and Hypertension in Elderly Chinese Subjects: $A$ Community Based Study. BMC Endocr Disord. 2016; $16: 40$ 
Table 1: Socio-demographic characteristics

\begin{tabular}{llll}
\hline S/N & Variable & $\begin{array}{l}\text { Frequency } \\
(\mathbf{n = 1 1 0})\end{array}$ & $\begin{array}{l}\text { Percentage } \\
(\mathbf{\%})\end{array}$ \\
\hline 1 & Gender: & & \\
& Male & 50 & 45.5 \\
& Female & 60 & 54.5 \\
& Age: & & \\
& $15-20$ & 26 & 23.6 \\
& $21-25$ & 76 & 69.1 \\
& $26-30$ & 8 & 7.3 \\
3 & Department: & & \\
& Nursing & 22 & 20.0 \\
& Pharmacology & 22 & 20.0 \\
& Medical Biochemistry & 22 & 20.0 \\
& Physiology & 22 & 20.0 \\
& Anatomy & 22 & 20.0 \\
4 & Level: & & \\
& 100 & 0 & 0 \\
& 200 & 36 & 32.7 \\
& 300 & 24 & 21.8 \\
& 400 & 50 & 45.5 \\
5 & State of Origin: & & \\
& Deltans & 93 & 84.5 \\
& Non-Deltans & 17 & 15.5 \\
\cline { 2 - 3 } & & &
\end{tabular}

Table 2: Blood glucose level measurement

\begin{tabular}{|c|c|c|c|}
\hline $\mathbf{S} / \mathbf{N}$ & FBG levels (mg/dL) & $\begin{array}{l}\text { Right thumb } \\
(n=40)\end{array}$ & $\begin{array}{l}\text { Left thumb } \\
(n=40)\end{array}$ \\
\hline 1 & $\begin{array}{l}\text { Hypoglycemia } \\
(<70 \mathrm{mg} / \mathrm{dL})\end{array}$ & $3 \quad(7.5 \%)$ & $\begin{array}{ll}4 & (10 \%)\end{array}$ \\
\hline 2 & $\begin{array}{l}\text { Normoglycemia } \\
(70 \text { to }<110 \mathrm{mg} / \mathrm{dL})\end{array}$ & $34 \quad(85 \%)$ & $35(87.5 \%)$ \\
\hline 3 & $\begin{array}{l}\text { Impaired Fasting Blood } \\
\text { Glucose Level } \\
(=110 \text { to }<126 \mathrm{mg} / \mathrm{dL})\end{array}$ & $2 \quad(5 \%)$ & $1 \quad(2.5 \%)$ \\
\hline 4 & $\begin{array}{l}\text { Hyperglycemia } \\
(=126 \mathrm{mg} / \mathrm{dL})\end{array}$ & $1 \quad(2.5 \%)$ & $0 \quad(0.0 \%)$ \\
\hline
\end{tabular}

Table 3: Performance of physical activity.

\begin{tabular}{llll}
\hline S/N & Physical activity & $\begin{array}{l}\text { Frequency } \\
\text { (n=110) }\end{array}$ & $\begin{array}{l}\text { Percentage } \\
\text { (\%) }\end{array}$ \\
\hline 1 & $\begin{array}{l}\text { Physical activity } \\
\text { (Light): }\end{array}$ & & \\
& $\begin{array}{l}\text { Frequently } \\
\text { (10 mins }-4 \text { hrs) }\end{array}$ & 68 & 61.8 \\
& $\begin{array}{l}\text { Occasionally } \\
(1-5 \text { mins) }\end{array}$ & 24 & 21.8 \\
& $\begin{array}{l}\text { Never } \\
\text { Physical activity } \\
\text { (Vigorous): }\end{array}$ & 18 & 16.4 \\
& $\begin{array}{l}\text { Frequently } \\
\text { (10 mins }-4 \text { hrs) }\end{array}$ & 25 & 22.7 \\
& $\begin{array}{l}\text { Occasionally } \\
\text { (1-5 mins) }\end{array}$ & 30 & 27.3 \\
Never & 55 & 50 \\
\hline
\end{tabular}


Table 4: Body mass index

\begin{tabular}{llll}
\hline S/N & BMI $\left(\mathbf{k g} / \mathbf{m}^{2}\right)$ & $\begin{array}{l}\text { Frequency } \\
(\mathbf{n = 1 1 0})\end{array}$ & $\begin{array}{l}\text { Percentage } \\
(\mathbf{\%})\end{array}$ \\
\hline 1 & $\begin{array}{l}\text { Underweight } \\
\left(<18.5 \mathrm{~kg} / \mathrm{m}^{2}\right)\end{array}$ & 12 & 10.9 \\
2 & $\begin{array}{l}\text { Normal weight } \\
\left(18.5-24.9 \mathrm{~kg} / \mathrm{m}^{2}\right.\end{array}$ & 80 & 72.7 \\
3 & $\begin{array}{l}\text { Over weight } \\
\left(25-29.9 \mathrm{~kg} / \mathrm{m}^{2}\right)\end{array}$ & 10 & 9.1 \\
4 & $\begin{array}{l}\text { Obese } \\
\left(=30 \mathrm{~kg} / \mathrm{m}^{2}\right)\end{array}$ & 8 & 7.3 \\
\hline
\end{tabular}

Table 5: Central obesity measurement

\begin{tabular}{|c|c|c|c|}
\hline $\mathbf{S} / \mathbf{N}$ & Central Obesity & $\begin{array}{l}\text { Frequency } \\
(n=110)\end{array}$ & $\begin{array}{l}\text { Percentage } \\
(\%)\end{array}$ \\
\hline 1 & $\begin{array}{l}\text { Normal } \\
(\mathrm{WHR}=0.95 \text { for male }) \\
(\mathrm{WHR}=0.8 \text { for female })\end{array}$ & 84 & 76.4 \\
\hline 2 & $\begin{array}{l}\text { Abnormal } \\
(\text { WHR }>0.95 \text { for male }) \\
(\text { WHR }>0.8 \text { for female })\end{array}$ & 26 & 23.6 \\
\hline
\end{tabular}

Table 6: Characteristics of subjects in terms of blood pressure

\begin{tabular}{llll}
\hline S/N & $\begin{array}{l}\text { Blood Pressure } \\
(\mathbf{m m H g})\end{array}$ & $\begin{array}{l}\text { Frequency } \\
(\mathbf{n = 1 1 0})\end{array}$ & $\begin{array}{l}\text { Percentage } \\
(\mathbf{\%})\end{array}$ \\
\hline 1 & $\begin{array}{l}\text { Hypotension } \\
(<90 / 60 \mathrm{mmHg})\end{array}$ & 0 & 0 \\
2 & $\begin{array}{l}\text { Normal BP } \\
(90 / 60-120 / 80 \mathrm{mmHg})\end{array}$ & 71 & 64.5 \\
3 & $\begin{array}{l}\text { Pre-Hypertension } \\
(121 / 81-139 / 89 \mathrm{mmHg})\end{array}$ & 30 & 27.3 \\
4 & $\begin{array}{l}\text { Stage }-1 \mathrm{Hypertension} \\
(140 / 90-159 / 99 \mathrm{mmHg})\end{array}$ & 8 & 7.3 \\
5 & $\begin{array}{l}\text { Stage }-2 \mathrm{Hypertension} \\
(>160 / 100 \mathrm{mmHg})\end{array}$ & 1 & 0.9 \\
\hline
\end{tabular}

